\title{
Emerging highly pathogenic H5 avian influenza viruses in France during winter 2015/16: phylogenetic analyses and markers for zoonotic potential
}

F Briand ${ }^{12}$, A Schmitz ${ }^{12}$, K Ogor $^{12}$, A Le Prioux ${ }^{12}$, C Guillou-Cloarec $^{12}$, C Guillemoto $^{12}$, C Allée $^{12}$, M Le Bras ${ }^{12}$, E Hirchaud ${ }^{2}$

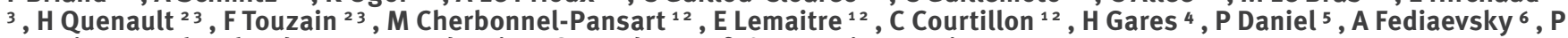

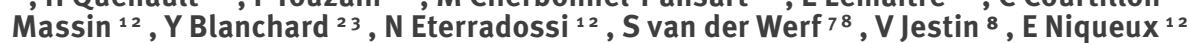

1. Anses, Unité VIPAC - LNR influenza aviaire, Ploufragan, France

2. Université Bretagne-Loire, Rennes, France

3. Anses, Unité Génétique Virale et Biosécurité, Ploufragan, France

4. Laboratoire Départemental d'Analyses et de Recherche, Coulounieix Chamiers, France

5. Laboratoire des Pyrénées et des Landes, Mont-de-Marsan, France

6. Direction Générale de l'Alimentation - MAAF, Paris, France

7. Institut Pasteur, Unité Génétique Moléculaire des Virus à ARN - CNR grippe, Paris, France

8. Anses - Groupe d’Experts Spécialisé Santé Animale et Bien-être Animal, Maisons-Alfort, France

Correspondence: François-Xavier Briand (francois-xavier.briand@anses.fr)

Citation style for this article:

Briand F, Schmitz A, Ogor K, Le Prioux A, Guillou-Cloarec C, Guillemoto C, Allée C, Le Bras M, Hirchaud E, Quenault H, Touzain F, Cherbonnel-Pansart M, Lemaitre E, Courtillon C, Gares H, Daniel P, Fediaevsky A, Massin P, Blanchard Y, Eterradossi N, van der Werf S, Jestin V, Niqueux E. Emerging highly pathogenic H5 avian influenza viruses in France during winter 2015/16: phylogenetic analyses and markers for zoonotic potential. Euro Surveill. 2017;22(9):pii=30473. DOI: http:// dx.doi.org/10.2807/1560-7917.ES.2017.22.9.30473

Article submitted on 02 March 2016 / accepted on 10 August 2016 / published on 02 March 2017

Several new highly pathogenic (HP) $\mathrm{H}_{5}$ avian influenza virus (AIV) have been detected in poultry farms from south-western France since November 2015, among which an $\mathrm{HP} \mathrm{H}_{5} \mathrm{~N}_{1}$. The zoonotic potential and origin of these AIVs immediately became matters of concern. One virus of each subtype $\mathrm{H}_{5} \mathrm{~N}_{1}$ (150169a), $\mathrm{H}_{5} \mathrm{~N}_{2}$ (150233) and $\mathrm{H}_{5} \mathrm{~N}_{9}$ (150236) was characterised. All proved highly pathogenic for poultry as demonstrated molecularly by the presence of a polybasic cleavage site in their HA protein - with a sequence (HQRRKR/ GLF) previously unknown among avian $\mathrm{H}_{5}$ HPAI viruses - or experimentally by the in vivo demonstration of an intravenous pathogenicity index of 2.9 for the $\mathrm{H}_{5} \mathrm{~N}_{1}$ HP isolate. Phylogenetic analyses based on the full genomes obtained by NGS confirmed that the eight viral segments of the three isolates were all part of avian Eurasian phylogenetic lineage but differed from the $\mathrm{Gs} / \mathrm{Gd} / 1 / 96$-like lineage. The study of the genetic characteristics at specific amino acid positions relevant for modulating the adaptation to and the virulence for mammals showed that presently, these viruses possess most molecular features characteristic of AIV and lack some major characteristics required for efficient respiratory transmission to or between humans. The three isolates are therefore predicted to have no significant pandemic potential.

\section{Introduction}

On 24 November 2015, a highly pathogenic (HP) $\mathrm{H}_{5} \mathrm{~N}_{1}$ avian influenza (Al) outbreak was confirmed by the French National Reference Laboratory (NRL) for avian influenza, in backyard layers and chickens in the Dordogne department, south-western France. From November 2015 to August 2016, a total of 80 highly pathogenic viruses have been identified, belonging to three different subtypes $\left(\mathrm{H}_{5} \mathrm{~N}_{1}, \mathrm{H}_{5} \mathrm{~N}_{2}, \mathrm{H}_{5} \mathrm{~N}_{9}\right)$.

In France, before 2015, the last $\mathrm{H}_{5} \mathrm{HPAl}$ event was limited to wild swans (Cygnus olor) and mallards (Anas platyrhynchos), in the eastern part of France during spring 2006 and summer 2007. It occurred almost concomitantly with outbreaks in wild birds and/or poultry in central Europe. The French $\mathrm{HPH}_{5}$ viruses isolated in 2006 and 2007 belonged to the $\mathrm{A} /$ goose/ Guangdong/1/1996 (Gs/Gd/1/96-like) lineage (clade 2.2 subgroup), as did the 2007 viruses from central Europe) [1-5]. Until 2014, $\mathrm{H}_{5} \mathrm{~N}_{1} \mathrm{HPAl}$ viruses belonging to the $\mathrm{Gs} / \mathrm{Gd} / 1 / 96$-like lineage have been maintained in south-east Asia, the Middle East and Egypt, in different locations and their haemagglutinin (HA) genes evolved continuously into a wide range of clades and subclades. They were reintroduced in West Africa and eastern Europe in 2015, and reassorted extensively, which in 2014 led to the emergence of new $\mathrm{H}_{5} \mathrm{~N} 6$ and $\mathrm{H}_{5} \mathrm{~N} 8$ HPAl subtypes (known as clade 2.3.4.4) in south-east Asia. The 2.3.4.4 H5N8 HPAl viruses spread to Europe (mainly the northern part) and to North America in late 2014. They are currently widespread in wildlife and poultry farms in the European Union (EU). In North America, they further reassorted as $\mathrm{H}_{5} \mathrm{~N}_{2}$ and $\mathrm{H}_{5} \mathrm{~N}_{1} \mathrm{HPAl}$, by incorporating neuraminidase (NA) genes of AIVs belonging to the American lineage. In the EU, recent reports also indicate reassortment as $\mathrm{H}_{5} \mathrm{~N}_{5} \mathrm{HPAl}$ 
Phylogenetic tree of the H5 gene sequences, three avian influenza H5 viruses, France, November 2015

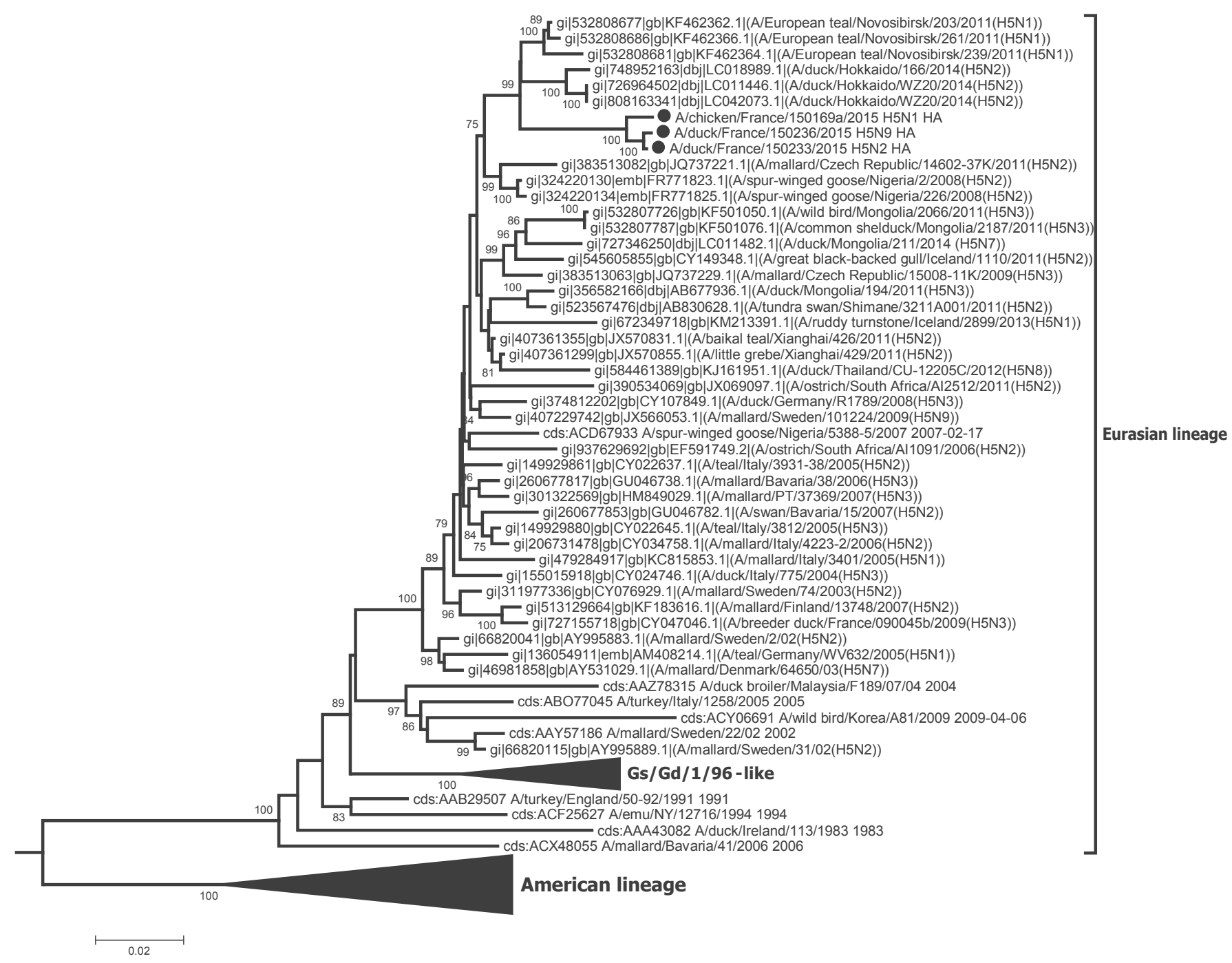

HA: haemagglutinin; HPAl: highly pathogenic avian influenza.

The complete coding sequences of the three $\mathrm{H}_{5}$ HPAI virus isolated from poultry in France were aligned with their closest related sequences as detected by BLAST, together with other sequences selected as representatives for more distant clusters. Then, the neighbour-joining method based on the Kimura-2 parameter model was applied using the MEGA 6 software [26] to obtain a phylogenetic tree with 1,000 bootstrap replicates. Only bootstrap values higher than $75 \%$ are shown. The HA sequences of French viruses are indicated with black dots. The tree was rooted by an $\mathrm{H} 2$ sequence.

[6]. However, no $\mathrm{Gs} / \mathrm{Gd} / 1 / 96$-like viruses have been detected in France before November 2015, except for the 2006 and 2007 outbreaks mentioned above [7-12].

In contrast, low pathogenic (LP) $\mathrm{H}_{5} \mathrm{~N}_{1}$, as well as $\mathrm{H}_{5} \mathrm{~N}_{2}$ and $\mathrm{H}_{5} \mathrm{~N}_{3}$ viruses, were detected in France in poultry, predominantly in domestic ducks, on several occasions [13-15], albeit seldom considering the fact that antibodies against $\mathrm{H}_{5}$ were regularly detected in sera of apparently healthy domestic ducks and geese during annual serological surveys [16-19].

The relationships between the $\mathrm{H}_{5} \mathrm{HPAl}$ viruses detected in November 2015 and other $\mathrm{H}_{5} \mathrm{HPAI}$ and LPAI viruses, including $\mathrm{H}_{5} \mathrm{~N}_{1}$ viruses previously detected in France and worldwide, as well as their zoonotic potential and origin were immediately matters of concern. Based on whole genome sequences established by next generation sequencing (NGS), this paper focuses on the phylogenetic relatedness of these newly isolated viruses and on their genetic characteristics at specific amino acid positions already reported as relevant for crossspecies transmission, adaptation to and virulence for mammals, including humans.

\section{Methods}

Three AIV subtypes were detected in south-western France during the winter 2015/16 ( $\left.\mathrm{H}_{5} \mathrm{~N}_{1}, \mathrm{H}_{5} \mathrm{~N}_{2}, \mathrm{H}_{5} \mathrm{~N} 9\right)$. 


\section{FIGURE 2}

Phylogenetic trees of the neuraminidase gene sequences (N1 segment), three avian influenza H5 viruses, France, November 2015
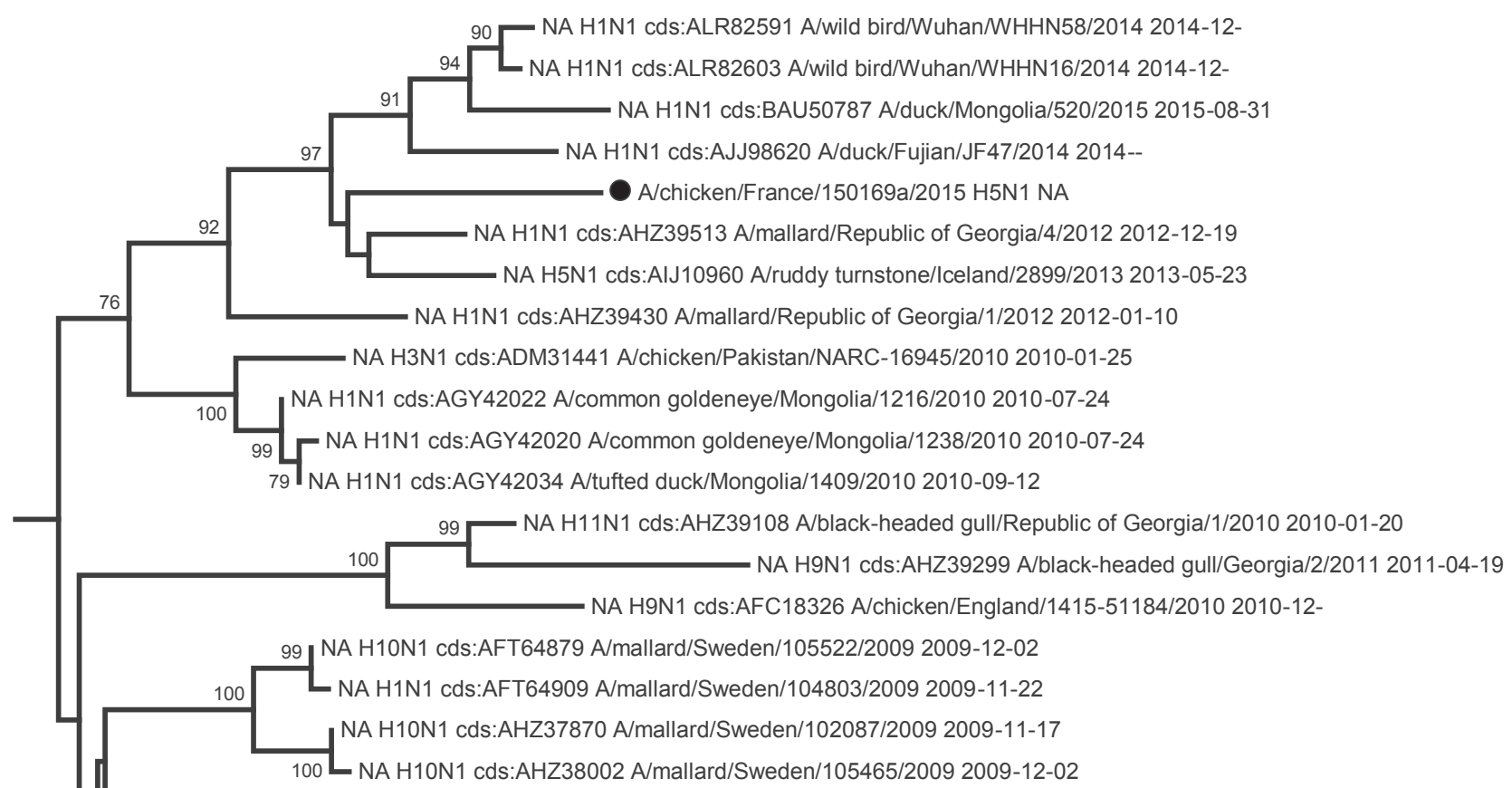

NA H11N1 cds:ADJ67499 A/aquatic bird/India/NIV-17095/2007 2007-12-23

NA H5N1 cds:AEO52314 A/duck/Zhejiang/2245/2011 2011-02-
NA H12N1 cds:AET80393 A/lesser whistling-duck/Thailand/CU-W3947/2010 2010-01-

100

L NA H12N1 cds:AET80403 A/lesser whistling-duck/Thailand/CU-W3946/2010 2010-01-

— NA H12N1 cds:AET80413 A/lesser whistling-duck/Thailand/CU-W3941/2010 2010-01-

NA H12N1 cds:AET80423 A/watercock/Thailand/CU-W3699/2009 2009-12-

NA H1N1 cds:AIA62013 A/duck/Korea/372/2009 2009-12-

77 NA H7N1 cds:AGY42057 A/ruddy shelduck/Mongolia/921C2/2009 2009-08-06

NA H12N1 cds:BAM77408 A/duck/Hokkaido/W26/2012 2012-10-04

95 NA H7N1 cds:AGY42019 A/common goldeneye/Mongolia/1271/2010 2010-07-24

— NA H3N1 cds:AGY42027 A/mallard/Mongolia/1551/2010 2010-09-10

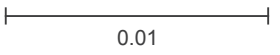

HA: haemagglutinin; HP: highly pathogenic; M: matrix; NA: neuraminidase; nt: nucleotide.

The complete coding sequence of the three different neuraminidases of French $\mathrm{H}_{5} \mathrm{HP}$ viruses were aligned with their closest related sequences as detected by BLAST, together with other sequences selected as representatives for more distant clusters. The neighbourjoining method based on the Kimura-2 parameter model was applied with the MEGA 6 software [26] to obtain a phylogenetic tree with 1,000 bootstrap replicates. Only bootstrap values higher than $75 \%$ are shown. The NA of French $\mathrm{H}_{5} \mathrm{HP}$ viruses are indicated by a black dot. The neuraminidase sequences from human viruses $\left(\mathrm{H}_{5} \mathrm{~N}_{1}\right.$ and $\left.\mathrm{H}_{9} \mathrm{~N}_{2}\right)$ were not represented in the $\mathrm{N}_{1}$ and $\mathrm{N}_{2}$ trees respectively (nt distances between these sequences and the French sequences are too high).

One representative of each subtype is described in the present paper.

\section{Outbreak description}

The first virus was isolated from an affected chicken in a suspected outbreak of avian influenza virus infections (150169a; $\mathrm{H}_{5} \mathrm{~N}_{1}$ ) declared to the local French animal health services on 19 November 2015. The affected flock was a backyard of 32 layer hens and broiler chickens, 9 to 10 months of age, located in Biras, Dordogne department. Die-off without any previous clinical signs caused a mortality rate of $69 \%$. Postmortem examination performed at the local veterinary diagnosis laboratory showed sub-cutaneous oedema of the head, neck and breast.

The second virus investigated here (150233; $\mathrm{H}_{5} \mathrm{~N}_{2}$ ) was obtained from a duck on a farm located in Manciet, 


\section{FIGURE 3}

Phylogenetic trees of the neuraminidase gene sequences (N2 segment), three avian influenza H5 viruses, France, November 2015

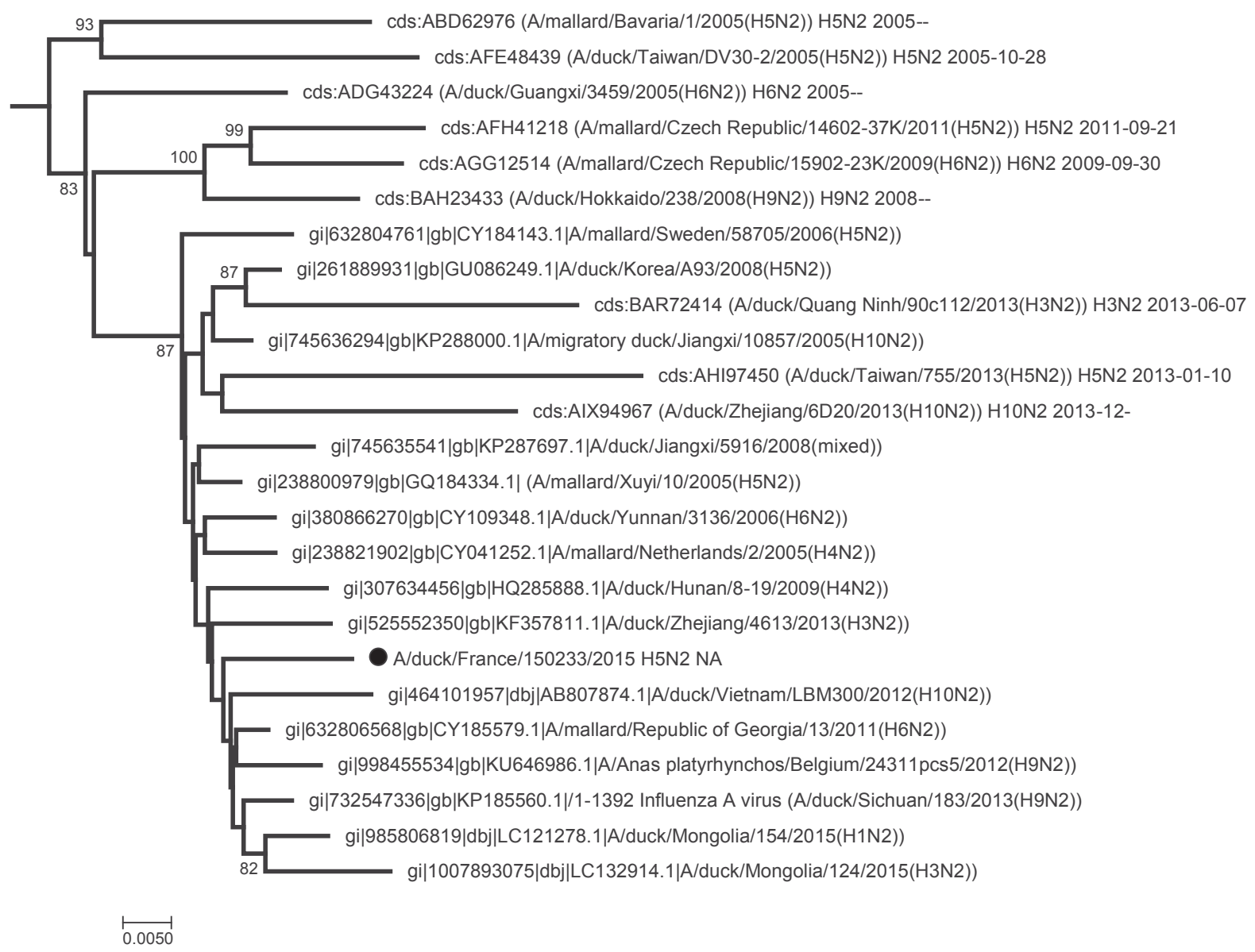

HA: haemagglutinin; HP: highly pathogenic; M: matrix; NA: neuraminidase; nt: nucleotide.

The complete coding sequence of the three different neuraminidases of French $\mathrm{H}_{5} \mathrm{HP}_{\mathrm{P}}$ iruses were aligned with their closest related sequences as detected by BLAST, together with other sequences selected as representatives for more distant clusters. The neighbourjoining method based on the Kimura-2 parameter model was applied with the MEGA 6 software [26] to obtain a phylogenetic tree with 1,000 bootstrap replicates. Only bootstrap values higher than $75 \%$ are shown. The NA of French $\mathrm{H}_{5} \mathrm{HP}$ viruses are indicated by a black dot. The neuraminidase sequences from human viruses $\left(\mathrm{H}_{5} \mathrm{~N}_{1}\right.$ and $\left.\mathrm{H}_{9} \mathrm{~N}_{2}\right)$ were not represented in the $\mathrm{N}_{1}$ and $\mathrm{N}_{2}$ trees respectively (nt distances between these sequences and the French sequences are too high).

Gers departement, maintaining 8,300 ducks for fattening and fatty liver production, where $3 \%$ mortality was observed on 8 December 2015.

The third virus (150236; $\mathrm{H}_{5} \mathrm{Ng}$ ) was from a duck in Arrosès, Pyrénées-Atlantiques departement, where a flock of 500 ducks raised for fatty liver production experienced a 5\% mortality on 9 December 2015.

\section{Detection, subtyping and molecular}

\section{pathotyping}

For each outbreak, RNA was extracted (RNeasy mini kit, Qiagen) from cloacal and oropharyngeal pools of five samples from dead birds. Samples were tested with the screening M-gene and $\mathrm{H}_{5}$ rRT-PCRs [20] by district laboratories. $\mathrm{H}_{5}$-positive samples were sent to NRL for further characterisation. The nucleotide (nt) sequences encompassing the cleavage site in the $\mathrm{HA}$ genes were amplified by the $\mathrm{J} / \mathrm{B} 2 \mathrm{a}$ or Kha1/Kha3 RT-PCRs [21]. Similarly, a portion of the NA gene was amplified by Pan NA RT-PCR [22]. PCR products were sequenced using the PCR primers. Subtype determination was performed by BLAST against sequences of the Influenza virus resource database [23]. The theoretical pathotype of the viruses was inferred from the cleavage site sequences according to the World Organisation for Animal Health (OIE) / Food and Agriculture Organisation (FAO) Network of expertise on animal Influenza (OFFLU) [24]. 
Phylogenetic trees of the neuraminidase gene sequences (N9 segment), three avian influenza H5 viruses, France, November 2015

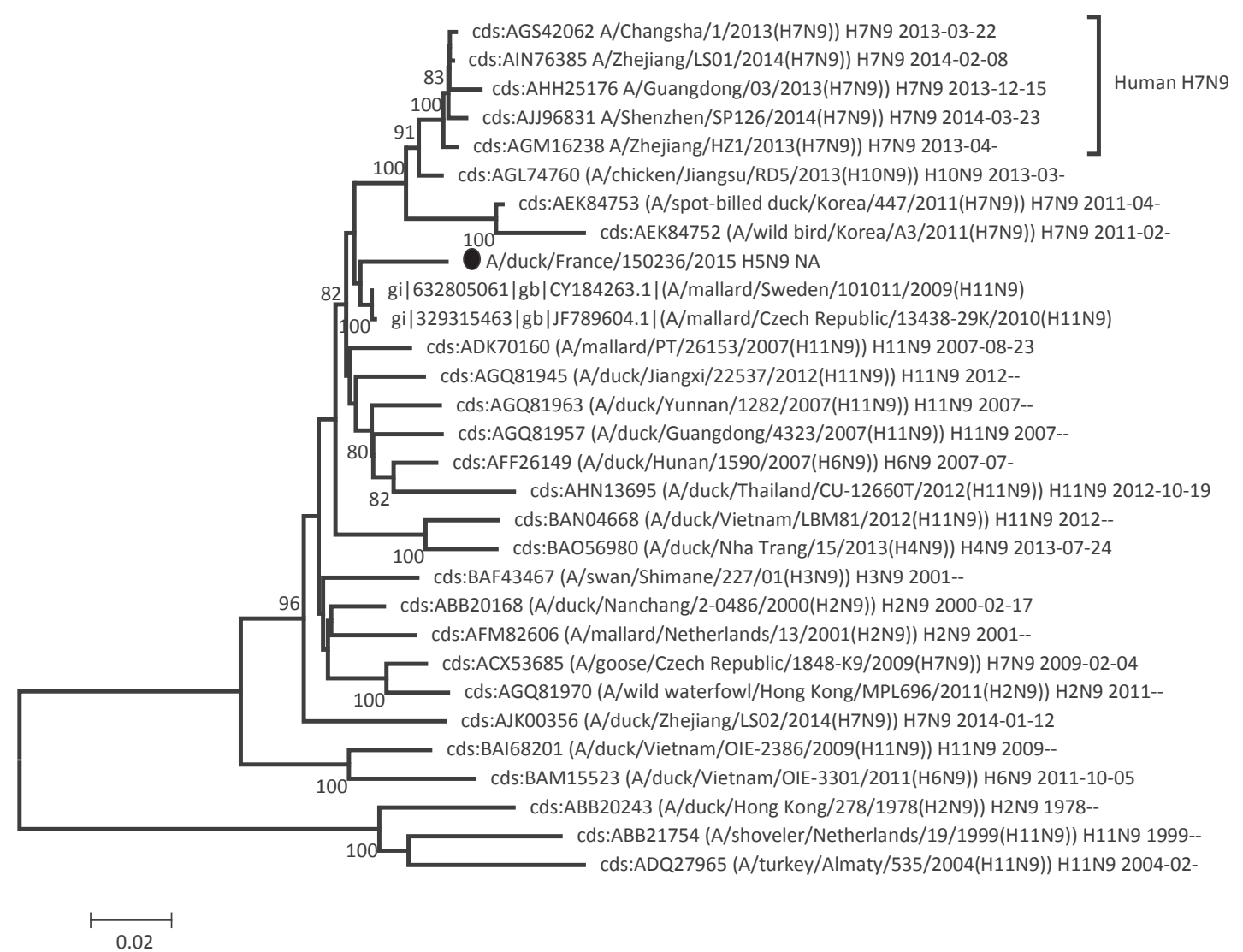

HA: haemagglutinin; HP: highly pathogenic; M: matrix; NA: neuraminidase; nt: nucleotide.

The complete coding sequence of the three different neuraminidases of French $\mathrm{H}_{5} \mathrm{HP}$ viruses were aligned with their closest related sequences as detected by BLAST, together with other sequences selected as representatives for more distant clusters. The neighbourjoining method based on the Kimura-2 parameter model was applied with the MEGA 6 software [26] to obtain a phylogenetic tree with 1,000 bootstrap replicates. Only bootstrap values higher than $75 \%$ are shown. The NA of French $\mathrm{H}_{5} \mathrm{HP}$ viruses are indicated by a black dot. The neuraminidase sequences from human viruses $\left(\mathrm{H}_{5} \mathrm{~N}_{1}\right.$ and $\left.\mathrm{H}_{9} \mathrm{~N}_{2}\right)$ were not represented in the $\mathrm{N}_{1}$ and $\mathrm{N}_{2}$ trees respectively (nt distances between these sequences and the French sequences are too high).

Virus isolation and in vivo characterisation Virus isolation was performed from individual tracheal and/or cloacal swabs, on 9-day-old specific pathogen free (SPF) eggs, and was positive after the first passage. Viral pathogenicity was confirmed through determination of the HA cleavage site sequence and in vivo by inoculation of the $\mathrm{H}_{5} \mathrm{~N}_{1} \mathrm{HP}$ 150169a isolate to 6.5-week-old SPF chickens, to establish the intravenous pathogenicity index (IVPI). All methods were conducted according to the OIE manual of standards for diagnostic tests and vaccines [25]. The IVPI experiment was performed according to international standards and was approved by the French Agency for Food, Environmental and Occupational Health and Safety (Anses)/National veterinary school of Alfort (ENVA)/ Paris-est Créteil University (UPEC) Ethics Committee (no.14-06o-18/11/14-6).
Library preparation, whole genome sequencing and NGS data analysis

Total RNA (170-20ong) was extracted from infected allantoic fluid and was treated with DNase, then was depleted from rRNA. cDNA libraries were prepared using the Ion Total RNA-Seq Kit (Life Technologies, Carlsbad, California, United States (US)) according to a protocol adapted from supplier's instructions (available upon request from the authors). The cDNA libraries were enriched then sequenced using the Ion Proton Sequencer and an Ion PI Chip v2 (Life Technologies). The resulting reads were cleaned with the Trimmomatic 0.32 software, then a Bowtie 2 alignment was performed on avian influenza genome references. The reads were down-sampled to fit a global coverage estimation of $80 x$ and were submitted to the SPAdes 3.1.1 de novo assembler. The de novo contigs were then 
TABLE 1

GenBank accession number, full reference and percent nucleotide identity of the complete coding sequences of the eight genome segments of three avian influenza H5 viruses with their closest genetic relatives, France, November 2015

\begin{tabular}{|c|c|c|c|}
\hline Segments & $\begin{array}{c}\text { Closest relatives of } \mathrm{H}_{5} \mathrm{~N}_{1} 150169 \mathrm{a} \\
\text { virus }\end{array}$ & $\begin{array}{c}\text { Closest relatives of } \mathrm{H}_{5} \mathrm{~N}_{2} 150233 \\
\text { virus }\end{array}$ & $\begin{array}{c}\text { Closest relatives of } \mathrm{H}_{5} \mathrm{~N} 9150236 \\
\text { virus }\end{array}$ \\
\hline PB2 & $\begin{array}{c}\mathrm{KM} 213385 \\
\mathrm{~A} / \text { ruddy turnstone/ } \\
\text { Iceland } / 2899 / 2013\left(\mathrm{H}_{5} \mathrm{~N}_{1}\right) \\
98,2\end{array}$ & $\begin{array}{c}\mathrm{KF} 918334 \\
\mathrm{~A} / \mathrm{Italy} / 3 / 2013\left(\mathrm{H}_{7} \mathrm{~N}_{7}\right) \\
97,5\end{array}$ & $\begin{array}{c}\text { KM213385 } \\
\text { A/ruddy turnstone/ } \\
\left.\text { Iceland/2899/2013( } \mathrm{H}_{5} \mathrm{~N}_{1}\right) \\
97,9 \\
\end{array}$ \\
\hline PB1 & $\begin{array}{c}\text { CY183997 } \\
\text { A/mallard/ } \\
\text { Sweden } / 133546 / 2011\left(\mathrm{H}_{10} \mathrm{~N}_{4}\right) \\
98,4\end{array}$ & $\begin{array}{c}\mathrm{KP} 137828 \\
\mathrm{~A} / \mathrm{harbour} \text { seal/ } \\
\text { Germany/1/2014(H10N7)) } \\
97,5\end{array}$ & $\begin{array}{c}\text { CYo41344 } \\
\text { A/common eider/ } \\
\text { Netherlands/1/2006(H3N8) } \\
97,2\end{array}$ \\
\hline PA & $\begin{array}{c}\text { CY185470 } \\
\text { A/common teal/Republic of } \\
\text { Georgia/1/2011(H3N8) } \\
98,2 \\
\end{array}$ & $\begin{array}{c}\text { CY184282 } \\
\text { A/mallard/ } \\
\text { Sweden } / 100878 / 2009\left(\mathrm{H}_{11} \mathrm{~N}_{9}\right) \\
98,3 \\
\end{array}$ & $\begin{array}{c}\text { KF874480 } \\
\text { A/wild waterfowl/Dongting/ } \\
\text { C2383/2012(H1N2) } \\
98,4\end{array}$ \\
\hline $\mathrm{HA}$ & $\begin{array}{c}\text { KF462362 } \\
\text { A/european teal/ } \\
\text { Novosibirsk/203/2011 }\left(\mathrm{H}_{5} \mathrm{~N}_{1}\right) \\
96,4 \\
\end{array}$ & $\begin{array}{c}\text { KF462362 } \\
\text { A/European teal/ } \\
\left.\left.\text { Novosibirsk/203/2011( } \mathrm{H}_{5} \mathrm{~N}_{1}\right)\right) \\
96,8 \\
\end{array}$ & $\begin{array}{c}\text { KF462362 } \\
\text { A/European teal/ } \\
\text { Novosibirsk/203/2011 }\left(\mathrm{H}_{5} \mathrm{~N}_{1}\right) \\
96,6 \\
\end{array}$ \\
\hline NP & $\begin{array}{c}\text { CY185468 } \\
\text { A/common teal/Republic of } \\
\text { Georgia/1/2011(H3N8) } \\
98,5\end{array}$ & $\begin{array}{c}\text { CY165689 } \\
\text { A/mallard } / \\
\text { Sweden } / 93211 / 2009\left(\mathrm{H}_{4} \mathrm{~N} 6\right) \\
97,3\end{array}$ & $\begin{array}{c}\text { CYo46143 } \\
\text { A/mallard } / \\
\left.\text { France/061054/2006(H }{ }_{5} \mathrm{~N}_{3}\right) \\
96,7\end{array}$ \\
\hline NA & $\begin{array}{c}\text { AlJ10960 } \\
\text { A/ruddy turnstone/ } \\
\text { Iceland } / 2899 / 2013\left(\mathrm{H}_{5} \mathrm{~N}_{1}\right) \\
98,2 \\
\end{array}$ & $\begin{array}{c}\text { CY185579 } \\
\text { A/mallard/Republic of } \\
\text { Georgia/13/2011(H6N2) } \\
98,1 \\
\end{array}$ & $\begin{array}{c}\text { CY184263 } \\
\text { A/mallard } / \\
\text { Sweden/101011/2009(H11N9) } \\
97,8\end{array}$ \\
\hline M & $\begin{array}{c}\mathrm{CY} 185341 \\
\mathrm{~A} / \mathrm{mallard} / \mathrm{Chany} / 425 / 2009\left(\mathrm{H}_{4} \mathrm{~N} 6\right) \\
99\end{array}$ & $\begin{array}{c}\text { CY183800 } \\
\text { A/mallard } / \\
\text { Sweden/64476/2007(H10N4) } \\
98,4 \\
\end{array}$ & $\begin{array}{c}\text { CY18380o } \\
\text { A/mallard/ } \\
\left.\text { Sweden } / 64476 / 2007\left(\mathrm{H}_{10} \mathrm{~N}_{4}\right)\right) \\
98,5 \\
\end{array}$ \\
\hline NS & $\begin{array}{c}\text { GQ907290 } \\
\text { A/bar headed goose/ } \\
\text { Mongolia/143/2005(H12 } 3 \text { ( }) \\
97,8\end{array}$ & $\begin{array}{c}\text { KF260032 } \\
\text { A/common teal/Hong Kong/ } \\
\text { MPD322/2007(H11N9) } \\
97,4\end{array}$ & $\begin{array}{c}\text { KF2600329 } \\
\text { A/common teal/Hong Kong/ } \\
\text { MPD322/2007(H11N9) } \\
97,3\end{array}$ \\
\hline
\end{tabular}

HA: haemagglutinin; NA: neuraminidase.

submitted to BLAST on a local nt database. For each segment the best matches were selected for a Bowtie 2 alignment, which produces very clean and robust 5' and 3 ' ends, contrary to de novo assemblies of viral genomes for which 5' and 3' ends are sometimes incomplete. Finally, the de novo assemblies and the alignment on the references were compared and the strict identities of the de novo and aligned sequences were assessed.

For each virus, the consensus of the eight avian influenza segments was submitted to the GenBank database (accession numbers KU310444 to KU310451, KXo14875 to KX014882 and KX014883 to KX01489o for isolates 150169, 150233 and 150336, respectively).

\section{Phylogenetic analysis}

For each segment, the sequences were aligned with most of the closest full-length related sequences, as obtained by BLAST, and with genetic sequences selected as representative of the segment genetic diversity. Then, the neighbour-joining method based on the Kimura-2 parameter model was applied using the MEGA 6 software [26] to obtain phylogenetic trees with 1,000 bootstrap replicates.

In silico analysis of molecular markers for transmission, replication and/or virulence in mammalian hosts

For the in silico prediction of the zoonotic potential of the new French viruses, the deduced amino acid sequences of viral proteins were analysed to search for the presence of residues previously known to be associated with increased transmission, replication, and/ or virulence in mammalian hosts. The analysis was based on the inventory provided by the US Centers for Disease Control and Prevention (CDC) [27] and on a recent review by Neumann et al. [28].

\section{Results}

Virus isolation and in vivo pathotyping Allantoic fluids with a haemagglutinating activity were collected from the inoculated embryonated eggs after the first passage of the three samples. 


\section{TABLE 2}

Percent nucleotide identity of the eight complete coding sequences between the three avian influenza $\mathrm{H} 5$ viruses, France, November 2015

\begin{tabular}{|l|c|c|c|c|c|c|c|}
\hline & PB2 & PB1 & PA & HA & NP & M & NS \\
\hline $\begin{array}{l}150169 \mathrm{a}\left(\mathrm{H}_{5} \mathrm{~N}_{1}\right) \text { to } \\
150233\left(\mathrm{H}_{5} \mathrm{~N} 2\right)\end{array}$ & 96.6 & 94.5 & 93.1 & 98.9 & 95.5 & 95.6 & 98.6 \\
\hline $\begin{array}{l}150169 \mathrm{a}\left(\mathrm{H}_{5} \mathrm{~N} 1\right) \\
150236\left(\mathrm{H}_{5} \mathrm{~N}_{9}\right)\end{array}$ & 97.5 & 94.9 & 94.4 & 98.8 & 92.3 & 95.9 & 98.7 \\
\hline $\begin{array}{l}150233\left(\mathrm{H}_{5} \mathrm{~N}_{2}\right) \\
150236\left(\mathrm{H}_{5} \mathrm{~N}\right)\end{array}$ & 96.4 & 93.3 & 93.4 & 99.8 & 91.6 & 99.5 & 99.2 \\
\hline
\end{tabular}

HA: haemagglutinin; NA: neuraminidase.

Isolates obtained from the allantoic fluids were further identified by $\mathrm{HI}$ test as $\mathrm{H}_{5}$ influenza viruses which were designated A/chicken/France/150169a/2015, A/duck/ France/150233/2015 and $A /$ duck/France/150236/2015 for the $\mathrm{H}_{5} \mathrm{~N}_{1}, \mathrm{H}_{5} \mathrm{~N}_{2}$ and $\mathrm{H}_{5} \mathrm{~N}_{9}$ isolates, respectively. Because the HA genes of the three isolates were so similar, and in order to reduce the number of animal experiments, only the first virus isolate, the 150169a $\mathrm{H}_{5} \mathrm{~N}_{1}$ virus, was tested in vivo for pathogenicity. Following intravenous inoculation, mortality was observed on the first day ( 3 of 10 birds died) and all inoculated birds had died on the second day. The IVPI was 2.9, close to its maximum value of 3 , and higher than the regulatory threshold value of 1.2 required to declare the isolate highly pathogenic [25].

\section{Sequence analysis}

Tables 1 and 2 present the closest genetically related avian influenza sequences, as identified by BLAST, and the percent $\mathrm{nt}$ identities between the three newly determined genomes, respectively. Although the three French HA sequences were close (nucleotide percent identities from 98.9 to 99.8 ), and shared a polybasic HQRRKR/GLF cleavage site not previously recognised in avian $\mathrm{H}_{5} \mathrm{HP}$ viruses [24], their internal genes proved more distant with percent identities ranging from 93.1 to 99.5 , and even more distant for the NA genes which belonged to the $\mathrm{N}_{1}, \mathrm{~N}_{2}$ and $\mathrm{N}_{9} \mathrm{NA}$ subtypes.

Phylogenetic analyses of the eight segments of the French viruses confirmed that they were all part of the avian Eurasian lineage, as illustrated for the HA and NA genes in Figures 1, 2, 3, 4.

The PB2 gene of the three French viruses belonged to a cluster including viruses from Europe, Gerogia, Iceland and notably one $\mathrm{H}_{9} \mathrm{~N}_{2}$ virus previously detected in France (GenBank accession number: $\mathrm{CY}_{0} 80412$ ) and one avian $\mathrm{HP} \mathrm{H}_{7} \mathrm{~N}_{7}$ virus detected from Italian poultry workers with conjunctivitis [29].

For the $\mathrm{PB} 1$ gene, the sequence of the $150169 \mathrm{a} \mathrm{H}_{5} \mathrm{~N}_{1}$ virus was grouped mainly with viruses from Georgia, Mongolia and Sweden. The $150233 \mathrm{H}_{5} \mathrm{~N}_{2}$ virus sequence was grouped with a Belgian $\mathrm{H}_{5} \mathrm{~N}_{2}$ and
Chinese sequences and a sequence of an $\mathrm{H}_{10} \mathrm{~N}_{7}$ virus isolated from a German harbor seal [30], whereas the sequence of the $150236 \mathrm{H}_{5} \mathrm{~N} 9$ virus was associated with sequences from various subtypes of AIVs from Sweden and the Netherlands.

The sequences of the PA segments clustered either with those of AIVs from Georgia, the Czech Republic, and the $\mathrm{H}_{10} \mathrm{~N}_{7}$ virus from harbour seals [30] (150169a $\mathrm{H}_{5} \mathrm{~N}_{1}$ isolate), or with virus sequences from Sweden and Norway ( $150233 \mathrm{H}_{5} \mathrm{~N}_{2}$ isolate), or with a group of sequences from Asian and Georgian viruses (150236 $\mathrm{H}_{5} \mathrm{~N} 9$ isolate).

The HA phylogenetic analysis showed that the sequences of three French $\mathrm{H}_{5} \mathrm{HP}$ clustered with those from Japanese, Mongolian and Russian viruses, but were not closely related to those of the $\mathrm{Gs} / \mathrm{Gd} / 1 / 96$-like clades which all grouped in a separate cluster with a $100 \%$ bootstrap value (Figure 1).

As already observed with $\mathrm{PB} 2$, the NP sequences of 150169a ( $\mathrm{H}_{5} \mathrm{~N}_{1}$ virus) and 150233 ( $\mathrm{H}_{5} \mathrm{~N}_{2}$ virus) were grouped with those of viruses from Europe, Georgia and Iceland, again including the avian $\mathrm{H}_{7} \mathrm{~N}_{7}$ isolated from poultry workers (A/Italy/3/2013) [29], whereas the NP gene of the French $150236 \mathrm{H}_{5} \mathrm{~N} 9 \mathrm{HP}$ was closely related with many other sequences from French $\mathrm{H}_{5}$ viruses isolated from 2006 to 2007 and with sequences from Dutch viruses.

The $\mathrm{N}_{1}$ gene sequence of $150169 \mathrm{a}_{5} \mathrm{~N}_{1}$ was related to sequences from viruses from Egypt, Georgia or Iceland. The Egyptian $\mathrm{N}_{1}$ sequence was from the avian $\mathrm{H}_{1} \mathrm{~N}_{1}$ subtype, and not from $\mathrm{H}_{5} \mathrm{~N}_{1}$ viruses with a zoonotic potential (Figure 2). The neuraminidase sequence from the $150233 \mathrm{H}_{5} \mathrm{~N}_{2}$ virus was close to an Asian N2 gene found in combination with several $\mathrm{HA}$ genes $\left(\mathrm{H}_{1}\right.$, $\mathrm{H}_{3}, \mathrm{H}_{4}, \mathrm{H}_{5}, \mathrm{H} 6, \mathrm{H}_{9}$ and $\mathrm{H}_{10}$ ) and to a sequence from a Belgian $\mathrm{H}_{9} \mathrm{~N}_{2}$ virus (Figure 3). The $\mathrm{N} 9$ sequence of isolate 150236 proved closest to several Swedish $\mathrm{H} 11 \mathrm{~N} 9$ sequences (Figure 4), and, although within a group with a significant bootstrap value, only distantly related with sequences from $\mathrm{H}_{7} \mathrm{~N} 9$ viruses with a zoonotic potential.

For the $M$ (matrix) gene sequences, only one large Eurasian cluster, including the three $\mathrm{H}_{5} \mathrm{HP}$ viruses, exhibited a bootstrap value higher than $75 \%$. This group included only four sequences of viruses from mammalian hosts, the aforementioned $\mathrm{H}_{7} \mathrm{~N}_{7}$ and $\mathrm{H}_{1} \mathrm{ON}_{7}$ viruses, as well as two $\mathrm{H}_{2} \mathrm{~N}_{2}$ and $\mathrm{H}_{4} \mathrm{~N}_{1}$ viruses detected in muskrat and swine, respectively [29-31].

Finally, the phylogenetic analysis of the three NS gene sequences indicated that they all belonged to a large cluster inside the A allele group, which contained sequences from African, Asian and European viruses, with only one sequence from a virus from a mammalian host, the swine $\mathrm{H}_{4} \mathrm{~N}_{1}$ virus [31]. 


\section{TABLE 3}

Amino acid residues in different genes of highly pathogenic $\mathrm{H} 5$ viruses, at positions previously identified to promote transmission, replication (in vitro or in vivo) or pathogenicity in mammalian hosts, or associated with decreased sensitivity to antivirals, France, $2015^{\mathrm{a}}$

\begin{tabular}{|c|c|c|c|c|c|}
\hline Protein & Aa substitution ${ }^{b}$ & $\begin{array}{l}\text { Aa present in the } \\
\text { French } \mathrm{H}_{5} \text { viruses }\end{array}$ & $\begin{array}{l}\text { The most represented } \\
\text { residue for European AIV } \\
\text { (\% of this residue) }{ }^{c}\end{array}$ & Comments $^{d}$ & PMIDe \\
\hline \multirow{5}{*}{ HA } & D94N & N94 & N94 (62.5) & $\begin{array}{l}\text { Increased binding to alpha } 2-6 \\
\text { receptor }\end{array}$ & 19020946 \\
\hline & S159N; T16oA & $\mathrm{N}_{159} ; \mathrm{A} 160$ & N159 (81.4); A16o (97.6) & $\begin{array}{l}\text { Increased binding to alpha } 2-6 \\
\text { receptor }\end{array}$ & $20427525 ; 19116267$ \\
\hline & S239P & P239 & P239 (99.4) & $\begin{array}{l}\text { Slightly increased binding to alpha } \\
\text { 2-6 receptor (aa } 239 \text { corresponds to } \\
\text { aa } 235 \text { in } \mathrm{H}_{5} \text { numbering) }\end{array}$ & 21637809 \\
\hline & T16oA & A16o & $\mathrm{A} 160(97.6)$ & $\begin{array}{l}\text { Increased airborne transmission } \\
\text { in ferrets; increased binding to } \\
\text { alpha2-6 receptor } \\
\text { (aa } 160 \text { corresponds to aa } 156 \text { in } \mathrm{H}_{5} \\
\text { numbering) }\end{array}$ & $22723413 ; 20427525$ \\
\hline & $\begin{array}{l}\text { Multibasic cleavage } \\
\text { site }\end{array}$ & HQRRKR/GLF & $\begin{array}{l}\text { Same sequence not found } \\
\text { in other European viruses }\end{array}$ & $\begin{array}{c}\text { Multiple basic residues in } \mathrm{H}_{5} \text { viruses } \\
\text { that are highly pathogenic for avian } \\
\text { hosts (but unique sequence) }\end{array}$ & $\begin{array}{c}\text { Same sequence not } \\
\text { found in other European } \\
\text { viruses }\end{array}$ \\
\hline \multirow{3}{*}{ PB2 } & $163 \mathrm{~T}$ & 163 & $163(99.2)$ & $\begin{array}{l}\text { Decreased pathogenicity in mice in } \\
\text { association with PB1 T677M }\end{array}$ & 21367983 \\
\hline & $\begin{array}{l}\text { L89V; G309D; } \\
\text { T339K; R477G; } \\
\text { I495V; A676T }\end{array}$ & $\begin{array}{l}\text { V89; D309; K339; } \\
\text { G477; V495; T676 }\end{array}$ & $\begin{array}{l}\text { V89 (99.7); D309 (99.5); } \\
\text { K339 (91.7); G477 (100); } \\
\text { V495 (99.4); T676 (98.3) }\end{array}$ & $\begin{array}{l}\text { Increased polymerase activity in } \\
\text { mouse cells }\end{array}$ & 19393699 \\
\hline & R368Q; Q447H & R368; Q447 & R368 (91.9); Q447 (99.9) & $\begin{array}{l}\text { Reduced virulence (lethality in mice) } \\
\text { and conferred histologic alteration in } \\
\text { the lungs, liver and brain of ferrets }\end{array}$ & $16533883 ; 15681421$ \\
\hline \multirow{4}{*}{ PB1 } & $\mathrm{K} 207 \mathrm{R}$ & $\mathrm{K} 207$ & $\mathrm{~K} 207(100)$ & Decreased polymerase activity & 17553873 \\
\hline & $\mathrm{Y}_{436 \mathrm{H}}$ & $Y_{436}$ & $Y_{436}(99.9)$ & $\begin{array}{l}\text { Decreased virulence in ducks, mice } \\
\text { and ferrets }\end{array}$ & 17553873 \\
\hline & V473L & V473 & V473 (99.5) & $\begin{array}{l}\text { Decreased polymerase activity in } \\
\text { mammalian cells and mice }\end{array}$ & 22090209 \\
\hline & $\mathrm{T} 677 \mathrm{M}$ & T677 & T677 (99.9) & $\begin{array}{l}\text { Increased polymerase activity in } \\
\text { vitro; reduced replication efficiency; } \\
\text { decreased virulence in mice in } \\
\text { association with } \mathrm{PB}_{2} \mathrm{I63T}\end{array}$ & 21367983 \\
\hline PB1-F2 & N66S & $\begin{array}{l}\mathrm{S} 66(150169 \mathrm{a}) ; \mathrm{N} 66 \\
(150233) ; \mathrm{PB} 1-\mathrm{F} 2 \\
\text { truncated }(150236) \\
\end{array}$ & N66 $(84,8) ;$ S66(15,1) & $\begin{array}{l}\text { Increased replication efficiency in } \\
\text { mice }\end{array}$ & 21852950 \\
\hline \multirow{2}{*}{ PA } & $T_{515} \mathrm{~A}$ & $\mathrm{~T}_{515}$ & $T_{515}(99.8)$ & Decreased polymerase activity & 17553873 \\
\hline & $\mathrm{R} 266 \mathrm{H} ; \mathrm{T}_{515} \mathrm{~S}$ & $\mathrm{R}_{266} \mathrm{~T}_{515}$ & R266 (99.8) T515 (99.8) & Reduced polymerase activity in vitro & 20211480 \\
\hline \multirow{2}{*}{ M1 } & N30D & D30 & D30 (99.9) & Increased virulence in mice & 19117585 \\
\hline & T215A & A215 & A215 (99.9) & Increased virulence in mice & 19117585 \\
\hline \multirow{5}{*}{ NS1 } & $\mathrm{P}_{42} \mathrm{~S}$ & $\mathrm{~S}_{42}$ & $\mathrm{~S}_{42}(66.0)$ & $\begin{array}{l}\text { Increased virulence (lethality in } \\
\text { mice and the systemic spread of } \\
\text { infection); } \\
\text { affected IFN pathway }\end{array}$ & 18032512 \\
\hline & E92D & D92 & D92 (99.8) & $\begin{array}{c}\text { Cytokine resistance using antiviral } \\
\text { activity assay }\end{array}$ & 12195436 \\
\hline & L103F; I106M & F103; M106 & $\mathrm{F}_{103}(65.7) ; \mathrm{M} 106$ (99.8) & $\begin{array}{l}\text { Increased virulence compared to WT } \\
\text { in mice }\end{array}$ & $19052083 ; 21593152$ \\
\hline & $\mathrm{N} 205 \mathrm{~S}$ & $\mathrm{~S} 205$ & S205 (64.9) & Implicated in high virulence in ferrets & 20862325 \\
\hline & $\begin{array}{l}\text { 227-230 (presence } \\
\text { of PDZ ligand } \\
\text { domain) }\end{array}$ & $\begin{array}{l}\text { Amino acid motif } \\
\quad(E S E V)\end{array}$ & $\begin{array}{l}\text { Amino acid motif (ESEV) } \\
(>80)\end{array}$ & $\begin{array}{l}\text { Amino acid motif (ESEV) increased } \\
\text { virulence and pathogenicity in mice }\end{array}$ & 18334632 \\
\hline NS2 & $\mathrm{T} 48 \mathrm{~A}$ & $\mathrm{~A} 48$ & A48 (66.2) & Implicated in high virulence in ferrets & 20862325 \\
\hline
\end{tabular}

Aa: amino acids; AIV: avian influenza viruses; HA: haemagglutinin; IFN: Interferon; M: matrix; NA: neuraminidase; WT. : wild type

${ }^{a}$ Markers for mammalian host adaptation or antiviral resistance were retrieved from [27] and the automated annotation of the studied sequence using the Influenza Research database [37].

${ }^{b} \mathrm{H}_{3}$ numbering for $\mathrm{HA}$ gene and numbering from the first methionine residue for other genes. Only positions where the sequence of French $\mathrm{H}_{5}$ HP viruses is consistent with a tropism for mammalian hosts are shown. For a more complete version with all positions shown, see ANSES table [12].

Percentage based on all complete protein sequences from viruses (all subtypes included except for the $\mathrm{H}_{5}$ and $\mathrm{N}_{1}$ genes) isolated in Europe and available in the Influenza Research database [37].

${ }^{d}$ Comments on the biological effect of the studied set of mutations as per [27,37], except authors' comment for the HA cleavage site.

e PMID numbers correspond to PubMed identifiers of cited references. 
Molecular markers for transmission, replication and/or virulence in mammalian hosts

The profiles of the three newly isolated viruses proved extremely similar in this respect, with only one position in the PB1-F2 protein differing between the three viruses.

Among the positions in the $\mathrm{HA}$ at which amino acid substitutions have been reported as potential determinants of host-range or of virulence for mammals, five were found in the HA of the new viruses ( $\mathrm{N}_{94}, \mathrm{~N}_{159}$, A160, $P_{239}$, polybasic cleavage site). However, the HA of the isolated $\mathrm{H}_{5} \mathrm{HP}$ viruses did not show the Q226L and $\mathrm{G}_{228 S}$ substitutions in the receptor-binding site of the $\mathrm{HA}$ that result in a switch of receptor binding preference from SAa2,3Gal to SAa2,6Gal [28].

Among the $\mathrm{PB} 2, \mathrm{~PB} 1$ and $\mathrm{PA}$ polymerase complex proteins, PB2 has been shown to harbour major determinants of host-restriction and adaptation. None of these two major substitutions were found in any of the viruses investigated here. In PB1, substitutions shown to increase virulence in mice $\left(\mathrm{V}_{3} \mathrm{~A} ; \mathrm{N}_{32} 8 \mathrm{~K} ; \mathrm{N}_{375} \mathrm{~S}\right)$ or to contribute to airborne transmission in mammals (H99Y; 1368V) were not present in the three new $\mathrm{H}_{5}$ HPAl viruses [32]. As shown in Table 3, at nine positions in $\mathrm{PB} 2$, three positions in PA and four positions in $\mathrm{PB} 1$ for which substitutions were shown to result in reduced polymerase activity or decreased virulence in mammals, the viruses exhibited residues typical of the vast majority $(91.7 \%-100 \%)$ of European AIV. No amino acid changes associated with increased polymerase activity, virulence or transmission in mammals were present in the nucleoprotein. In the $M$ protein, the viruses isolated in France since November 2015, as more than $99 \%$ of European AIV, harboured amino acids D30 and T215 associated with increased virulence for mice.

In the $\mathrm{PB}_{1}-\mathrm{F}_{2}$ of the $150169 \mathrm{a} \mathrm{H}_{5} \mathrm{~N}_{1}$ virus, the N66S substitution is observed as in HPAl $\mathrm{H}_{5} \mathrm{~N}_{1}$ (Gs/Gd/1/96-like) and the 1918 pandemic virus. This substitution was not observed in the $150233 \mathrm{H}_{5} \mathrm{~N}_{2}$ or $150236 \mathrm{H}_{5} \mathrm{~N} 9$ viruses, the latter apparently exhibiting a truncated PB1-F2 ORF with a premature stop codon at position 26 .

The NS1 protein is a major antagonist of the antiviral host responses. Among substitutions in NS1 associated with enhanced interferon antagonistic activity or that contribute to increased virulence in mammals, the $\mathrm{P}_{42} \mathrm{~S}, \mathrm{E}_{92} \mathrm{D}, \mathrm{L}_{103} \mathrm{~F}$ and $\mathrm{I}_{106 \mathrm{M}}$, and $\mathrm{N}_{205} \mathrm{~S}$ mutations were present in the NS1 of these three French HP viruses as in the majority ( $>65 \%$ ) of European AIV. Furthermore, the ESEV PDZ-ligand domain, identified as an important virulence determinant, was present at the $\mathrm{C}$-terminus of $\mathrm{NS}_{1}$ of the three French $\mathrm{H}_{5}$ viruses, as for more than $80 \%$ of European AIV.

Based on known substitutions in the $\mathrm{M}_{2}$ or the $\mathrm{N}_{1}$ that confer resistance or reduced susceptibility to antivirals, it could be considered that the French viruses are sensitive to both $\mathrm{M} 2$-blockers (amantadine, rimantadine) and neuraminidase inhibitors (zanamivir, oseltamivir, peramivir).

\section{Discussion}

The unusual cleavage site corresponding to HP viruses observed in the November/December 2015 AIV circulation episode indicated that the acquisition of multiple basic residues did not occur by insertions as observed in the $\mathrm{H}_{5} \mathrm{HA}$ from $\mathrm{Gs} / \mathrm{Gd} / 96$-like viruses, but rather by substitution. Between positions 1009 to 1035 of the $\mathrm{H}_{5}$ encoding region, at least five nt substitutions were observed between the new French $\mathrm{H}_{5} \mathrm{HP}$ and the closest $\mathrm{H}_{5}$ sequences. In addition, the full genome sequencing by NGS of the three French $\mathrm{H}_{5}$ HP virus isolates confirmed the presence of three different NA subtypes. The existence of reassortment events can be directly inferred from the finding that three different neuraminidases ( $\mathrm{N}_{1}, \mathrm{~N}_{2}$ and $\mathrm{N}_{9}$ ) were associated with very similar and original $\mathrm{H}_{5} \mathrm{HP}$ sequences. This result seems to be confirmed by the phylogenetic analyses of the internal genes. Indeed, the internal genes of the three $\mathrm{H}_{5} \mathrm{HP}$ viruses were not always directly closely related (higher percent identities in Table 1, as compared with Table 2). This demonstrates that the three viruses were not simply derived from a single $\mathrm{H}_{5} \mathrm{HP}$ ancestor through reassortment events leading to the acquisition of three different neuraminidases. More detailed analyses of the reassortment events will be made when other full genomes are sequenced, including non HP influenza viruses detected in the same area during the virological surveillance of the epizootic, which could have acted as partners in the reassortment events. Unfortunately, this research has been postponed due to the need to investigate the subsequent 2016/17 AIV circulation episode (due to $\mathrm{H}_{5} \mathrm{~N} 8$ HPAI); in spite of intense virological surveillance, this investigation did not detect circulation of the 2015/16 $\mathrm{H}_{5} \mathrm{HPAl}$ viruses.

Overall, based on the analysis of the sequences, only few residues that may increase transmission, replication and/or virulence in mammalian hosts were detected in the viruses analysed here. These residues were shared by the majority of other contemporary AIVs. To what extent the observed substitutions in the HA (N94, N159, A160, P234 and poly basic cleavage site) could contribute to the ability to bind the human SAa2,6Gal receptors in addition to avian SAa2,3Gal receptors needs to be evaluated in receptor-binding assays [33]. Such feature could potentially contribute to the ability of the virus to bind to both the upper and lower respiratory tract in humans. However, as for other European AIV including HPAI viruses, the polymerase complex proteins, the NP and the $M_{1}$ of these viruses lack the major features associated with increased efficiency of replication in mammals. This does not preclude the possibility that under particular circumstances e.g. massive exposure or individual genetic susceptibility, infection in humans might occur 
and result in severe infections. Indeed, these viruses exhibit a multibasic cleavage site in their $\mathrm{HA}$, that provides potential for systemic spread, and determinants in PB1-F2 and NS1 associated with an increased virulence in mammals and/or with the ability to antagonise the antiviral host response more efficiently.

However, the viruses did not exhibit the combinations of mutations found to be required for respiratory droplet transmission in ferrets $[32,34,35]$. These include (i) mutations in the $\mathrm{HA}$ that allow $\mathrm{H}_{5} \mathrm{HA}$ binding to the SAa2,6Gal receptor as observed in human influenza viruses (N224K, Q226L, G228S); (ii) mutations resulting in the loss of a glycosylation site at position 158-160 in the HA that favours binding to the human SAa2,6Gal receptors; (iii) mutations at the HA trimer interface ( $\mathrm{H}_{110 \mathrm{Y}}$; T318I) that increase the stability of the $\mathrm{HA}$ and result in a reduction of the optimal $\mathrm{pH}$ at which the conformational change required for fusion occurs; (iv) mutations in PB2 (E627K and D701N substitutions were considered as major determinants of adaptation to mammals $[35,36])$ and PB1 (H99Y) that ensure efficient viral replication in mammalian cells.

Hence, even in the very unlikely event of human infection with the 2015/16 H5 HPAIV, further humanto-human transmission is not anticipated and the pandemic potential of these viruses can be considered to be negligible.

\section{Conflict of interest}

None declared.

\section{Authors' contributions}

KO, ALP, CGC, CG, CA, MOLB, MCP, EL, CC: Samples processing, RT-PCR, pathotyping, egg isolation at NRL.

FXB, AS, EN, AF, NE: Design and supervision.

EH, HQ, FT, YB: NGS sequencing and analyses.

FXB: Phylogenetic analysis.

HG, PD: Screening samples (local veterinary diagnosis laboratory).

EN, SVDW, YB, VJ, FXB, NE: Manuscript writing.

PM: Table and manuscript revision.

\section{References}

1. Haase M, Starick E, Fereidouni S, Strebelow G, Grund C, Seeland $A$, et al. Possible sources and spreading routes of highly pathogenic avian influenza virus subtype $\mathrm{H}_{5} \mathrm{~N}_{1}$ infections in poultry and wild birds in Central Europe in 2007 inferred through likelihood analyses. Infect Genet Evol. 2010;10(7):1075-84. DOI: 10.1016/j.meegid.2010.07.005 PMID: 20624487

2. Hars J, Ruette S, Benmergui M, Fouque C, Fournier JY, Legouge $A$, et al. The epidemiology of the highly pathogenic $\mathrm{H}_{5} \mathrm{~N}_{1}$ avian influenza in Mute Swan (Cygnus olor) and other Anatidae in the Dombes region (France), 2006. J Wildl Dis.
2008;44(4):811-23. DOI: 10.7589/0090-3558-44.4.811 PMID: 18957637

3. Gall-Reculé GL, Briand FX, Schmitz A, Guionie O, Massin $P$, Jestin V. Double introduction of highly pathogenic $\mathrm{H}_{5} \mathrm{~N}_{1}$ avian influenza virus into France in early 2006. Avian Pathol. 2008;37(1):15-23. DOI: 10.1080/03079450701774835 PMID: 18202945

4. Starick E, Beer M, Hoffmann B, Staubach C, Werner O, Globig A, et al. Phylogenetic analyses of highly pathogenic avian influenza virus isolates from Germany in 2006 and 2007 suggest at least three separate introductions of $\mathrm{H}_{5} \mathrm{~N}_{1}$ virus. Vet Microbiol. 2008;128(3-4):243-52. DOI: 10.1016/j. vetmic.2007.10.012 PMID: 18031958

5. European Food Safety Authority (EFSA). Scientific Opinion of the Panel on Animal Health and Welfare on a request from The European Commission on Animal health and welfare aspects of avian influenza and the risk of its introduction into the EU poultry holdings.EFSA J. 2008;715:1-161.

6. World Organisation for Animal Health (OIE). Rapport de notification immediate. [Immediate notification report]. OIE: Paris; 14 Dec 2016. French. Available from: http:// www.oie.int/wahis_2/public $\% 5$ C.\%5Ctemp $\% 5$ Creports/ fr_imm_0000021909_20161215_141530.pdf

7. Smith GI, Donis RO, World Health Organization/World Organisation for Animal Health / Food and Agriculture Organization (WHO/OIE/FAO) H5 Evolution Working Group. Nomenclature updates resulting from the evolution of avian influenza $\mathrm{A}\left(\mathrm{H}_{5}\right)$ virus clades 2.1.3.2a, 2.2.1, and 2.3.4 during 2013-2014. Influenza Other Respir Viruses. 2015;9(5):271-6. DOI: 10.1111 /irv.12324

8. European Food Safety Authority (EFSA). Highly pathogenic avian influenza A subtype H5N8.EFSA J. 2014;12(12):3941. DOI: 10.2903/j.efsa.2014.3941

9. Food and Agriculture Organization of the United Nations (FAO). Avian influenza $\mathrm{A}\left(\mathrm{H}_{5} \mathrm{~N} 6\right)$ : the latest addition to emerging zoonotic avian influenza threats in East and Southeast Asia. Rome: FAO; Nov 2014. Available from: http://www.fao.org/3/ai4199e.pdf

10. World Health Organization (WHO). Updated unified nomenclature system for the highly pathogenic $\mathrm{H}_{5} \mathrm{~N}_{1}$ avian influenza viruses. Geneva: WHO; Oct 2011. Available from: http://www.who.int/influenza/gisrs_laboratory/ h5n1_nomenclature/en/

11. World Health Organization (WHO). Antigenic and genetic characteristics of zoonotic influenza viruses and development of candidate vaccine for pandemic preparedness.Wkly Epidemiol Rec. 2015;12(90):11.

12. Agence nationale de sécurité sanitaire de l'alimentation, de l'environnement et du travail (ANSES). Avis de l'Agence nationale de sécurité sanitaire de l'alimentation, de l'environnement et du travail relatif au risque Influenza aviaire. [Opinion of the French Agency for Food, Environmental and Occupational Health and Safety regarding avian influenza risk]. Maisons-Alfort: ANSES; 14 Dec 2015. French. Available from: https://www.anses.fr/fr/system/files/SANT2015sa0241.pdf

13. Briand FX, Le Gall-Reculé G, Guillou-Cloarec C, Ogor K, Jestin $\mathrm{V}$. Phylogeny and genotyping of recent avian low-pathogenic $\mathrm{H} 5$ subtype influenza viruses from French ducks.J Gen Virol. 2010;91(Pt 4):960-70. DOI: 10.1099/vir.0.016733-o PMID: 20016038

14. Cherbonnel M, Lamandé J, Allée C, Schmitz A, Ogor K, Le GallReculé $\mathrm{G}$, et al. Virologic findings in selected free-range mule duck farms at high risk for avian influenza infection. Avian Dis. 2007;51(1) Suppl;408-13. DOI: 10.1637/7595-040306R1.1 PMID: 17494595

15. World Organisation for Animal Health (OIE). Immediate notification of $\mathrm{H}_{5} \mathrm{~N}_{1}$ highly pathogenic avian influenza in France. REF OIE 19171, Report Date: 24/11/2015, Country: France. 2015; Report 24 Nov 2015. Available from: http:// www.oie.int/wahis_2/public \%5C.\%5Ctemp\%5Creports/ fr_imm_0000019171_20151125_164439.pdf

16. Guerry I, Sadonès H, Schmitz A, Niqueux E, Briand F-X, Jestin V. Bilan de la surveillance de l'influenza aviaire et de la maladie de Newcastle en France en 2013. [Summary of surveillance for avian Influenza and Newcastle disease in France, 2013]. Bull Epid Santé Anim Alim. 2014;64:54-9. Available from: http:// bulletinepidemiologique.mag.anses.fr/sites/default/files/BEPmg-BE64-art14.pdf

17. Jestin V, Schmitz A, Niqueux E, Briand FX, Brochet AL, Picault JP, et al. Maintien des objectifs et modalités de la surveillance de l'influenza aviaire en 2009: bilan stable par rapport à 2008 . [Maintained objectives and means for surveillance of avian influenza in 2009: Stable situation as compared with 2008]. Bull Epid Santé Anim Alim. 2010;40:41-46. French. Available from: http://bulletinepidemiologique.mag.anses.fr/sites/ default/files/BEP-mg-BE40_o.pdf 
18. Sadonès H, Hars J, Schmitz A, Briand FX, Niqueux E. Surveillance de l'influenza aviaire et de la maladie de Newcastle en France en 2011. [Summary of surveillance for avian Influenza and Newcastle disease in France, 2011]. Bull Epid Santé Anim Alim. 2012;54:49-53. French. Available from: http://bulletinepidemiologique.mag.anses.fr/sites/default/ files/BEP-mg-BE54.pdf

19. Sadonès H, Schmitz A, Niqueux N, Briand FX, Jestin V. Surveillance de l'influenza aviaire en France en 2010. [Summary of surveillance for avian Influenza and Newcastle disease in France, 2010]. Bull Epid Santé Anim Alim. 2011;46:44-48. French. Available from: http:// bulletinepidemiologique.mag.anses.fr/sites/default/files/BEPmg-BE46.pdf

20. Slomka MJ, Coward VJ, Banks J, Löndt BZ, Brown IH, Voermans $J$, et al. Identification of sensitive and specific avian influenza polymerase chain reaction methods through blind ring trials organized in the European Union. Avian Dis. 2007;51(1) Suppl;227-34. DOI: 10.1637/7674-063006R1.1 PMID: 17494558

21. Spackman E, Senne DA, Myers TJ, Bulaga LL, Garber LP, Perdue $M L$, et al. Development of a real-time reverse transcriptase PCR assay for type A influenza virus and the avian $\mathrm{H}_{5}$ and $\mathrm{H}_{7}$ hemagglutinin subtypes. J Clin Microbiol. 2002;40(9):3256-60. DOI: $10.1128 / J C M .40 .9 \cdot 3256-3260.2002$ PMID: 12202562

22. Gall A, Hoffmann B, Harder T, Grund C, Höper D, Beer $M$. Design and validation of a microarray for detection, hemagglutinin subtyping, and pathotyping of avian influenza viruses.J Clin Microbiol. 2009;47(2):327-34. DOI: 10.1128/ JCM.01330-08 PMID: 19052173

23. Bao Y, Bolotov P, Dernovoy D, Kiryutin B, Zaslavsky L, Tatusova $T$, et al. The influenza virus resource at the National Center for Biotechnology Information. J Virol. 2008;82(2):596-601. DOI: 10.1128/JVI.02005-07 PMID: 17942553

24. World Organisation for Animal Health (OIE) / Food and Agriculture Organisation (FAO) Network of expertise on animal Influenza (OFFLU). Influenza A cleavage sites 2016. OIE/FAO. Available from: http://www.offlu.net/fileadmin/home/en/ resource-centre/pdf/Influenza_A_Cleavage_Sites.pdf

25. World Organisation for Animal Health (OIE). Chapter 2.3.4, Avian Influenza. in Manual of diagnostic tests and vaccines for terrestrial animals Paris, France: OIE; 2015. http:// www.oie.int/fileadmin/Home/eng/Health_standards/ tahm/2.03.04_Al.pdf

26. Tamura K, Stecher G, Peterson D, Filipski A, Kumar S. MEGA6: Molecular Evolutionary Genetics Analysis version 6.0. Mol Bio Evol. 2013;30(12):2725-9. DOI: 10.1093/molbev/mst197 PMID: 24132122

27. Centers for Disease Control and Prevention (CDC). $\mathrm{H}_{5} \mathrm{~N}_{1}$ genetic changes inventory: a tool for influenza surveillance and preparedness. Atlanta: CDC; 21 Jun 2012. Available from: http://www.cdc.gov/flu/pdf/avianflu/h5n1-inventory.pdf

28. Neumann G, Kawaoka Y. Transmission of influenza $A$ viruses.Virology. 2015;479-480:234-46. DOI: 10.1016/j. virol.2015.03.009 PMID: 25812763

29. Puzelli S, Rossini G, Facchini M, Vaccari G, Di Trani L, Di Martino A, et al. . Human infection with highly pathogenic $\mathrm{A}\left(\mathrm{H}_{7} \mathrm{~N}_{7}\right)$ avian influenza virus, Italy, 2013. Emerg Infect Dis. 2014;20(10):1745-9. DOI: 10.3201/eid2010.140512 PMID: 25271444

30. Bodewes R, Bestebroer TM, van der Vries E, Verhagen JH, Herfst S, Koopmans MP, et al. Avian Influenza $\mathrm{A}\left(\mathrm{H}_{10} \mathrm{~N}_{7}\right)$ virusassociated mass deaths among harbor seals. Emerg Infect Dis. 2015;21(4):720-2. DOI: 10.3201/eid2104.141675 PMID: 25811303

31. Hu Y, Liu X, Li S, Guo X, Yang Y, Jin M. Complete genome sequence of a novel $\mathrm{H}_{4} \mathrm{~N}_{1}$ influenza virus isolated from a pig in central China.J Virol. 2012;86(24):13879. DOI: 10.1128/ JVI.02726-12 PMID: 23166273

32. Linster $M$, van Boheemen S, de Graaf M, Schrauwen EJ, Lexmond P, Mänz B, et al. Identification, characterization, and natural selection of mutations driving airborne transmission of $\mathrm{A} / \mathrm{H}_{5} \mathrm{~N}_{1}$ virus. Cell. 2014;157(2):329-39. DOI: 10.1016/j. cell.2014.02.040 PMID: 24725402

33. Walther T, Karamanska R, Chan RW, Chan MC, Jia N, Air G, et al. Glycomic analysis of human respiratory tract tissues and correlation with influenza virus infection. PLoS Pathog. 2013;9(3):e1003223. DOI: 10.1371/journal.ppat.1003223 PMID: 23516363

34. Imai M, Watanabe T, Hatta M, Das SC, Ozawa M, Shinya K, et al. Experimental adaptation of an influenza $\mathrm{H}_{5} \mathrm{HA}$ confers respiratory droplet transmission to a reassortant $\mathrm{H}_{5} \mathrm{HA}$ $\mathrm{H}_{1} \mathrm{~N}_{1}$ virus in ferrets. Nature. 2012;486(7403):420-8.PMID: 22722205

35. Herfst S, Imai M, Kawaoka Y, Fouchier RA. Avian influenza virus transmission to mammals.Curr Top Microbiol Immunol. 2014;385:137-55. DOI: 10.1007/82_2014_387 PMID: 25048542
36. Rodriguez-Frandsen A, Alfonso R, Nieto A. Influenza virus polymerase: Functions on host range, inhibition of cellular response to infection and pathogenicity.Virus Res. 2015;209:23-38. DOI: 10.1016/j.virusres.2015.03.017 PMID: 25916175

37. Influenza Research database (IRD). IRD Search tools. [Accessed Dec 2015]. Available from: http://www.fludb.org/brc/search_ landing.spg?decorator=influenza

\section{License and copyright}

This is an open-access article distributed under the terms of the Creative Commons Attribution (CC BY 4.0) Licence. You may share and adapt the material, but must give appropriate credit to the source, provide a link to the licence, and indicate if changes were made.

This article is copyright of the authors, 2017. 